\title{
Cell Wall Composition and Surface Properties in Bacillus subtilis: Anomalous Effect of Incubation Temperature on the Phage-binding Properties of Bacteria Containing Varied Amounts of Teichoic Acid
}

\author{
By A. R. ARCHIBALD, ${ }^{*}$ K. GLASSEY, R. S. GREEN AND W. K. LANG $\dagger$ \\ The Microbial Technology Group, Department of Microbiology, University of Newcastle upon \\ Tyne, Framlington Place, Newcastle upon Tyne NE2 4HH, UK
}

(Received 1 August 1988; revised 4 November 1988; accepted 15 November 1988)

\begin{abstract}
Adsorption of bacteriophage SP50 to walls and heat-killed cells of Bacillus subtilis 168 appeared to be irreversible at both 37 and $0{ }^{\circ} \mathrm{C}$. Few, if any, active phage were desorbed when phage-wall complexes, formed at either temperature, were suspended in fresh medium. Bacteria rich in wall teichoic acid (TA) bound phage rapidly at both 0 and $37^{\circ} \mathrm{C}$, binding at the higher temperature being approximately twice as fast. Bacteria containing diminished proportions of TA showed less rapid phage adsorption but the reduction in rate was greater at 37 than at $0{ }^{\circ} \mathrm{C}$ and bacteria containing only small proportions of TA bound phage more rapidly at $0{ }^{\circ} \mathrm{C}$ than they did at $37^{\circ} \mathrm{C}$. These findings show that at low phage receptor density the temperature affects some component(s) involved in the phage-bacterium interaction such that the collision efficiency is increased at the lower temperature. The possible effect of temperature on the organization of bacterial surface components is discussed.
\end{abstract}

\section{INTRODUCTION}

Teichoic acids (TAs) are integral components of the cell wall in many Gram-positive bacteria. They are important determinants of both specific surface properties such as antigenicity, and non-specific surface properties such as charge, polarity and hydrophobicity (Archibald, 1988). The arrangement of TAs and the other component polymers within the wall and at the surface is affected by its ionic environment. The latter can modify the structural properties of the wall (Ou \& Marquis, 1970), the nature of the groups at the surface (James \& Brewer, 1968) and the conformation of wall polymers (Doyle et al., 1974) as well as specific surface properties such as the ability to bind phages.

Quantitative studies on the relation between TA content and surface properties have been made possible by the finding that when grown under conditions of controlled phosphate supply various bacilli replace all (Ellwood \& Tempest, 1969) or part (Anderson et al., 1978a) of the wall TA by an alternative anionic polymer, teichuronic acid (TU). We have examined the effect of varied wall composition in Bacillus subtilis on surface charge (Archibald, 1988) and on the abilities to bind concanavalin A (Lang \& Archibald, 1983) and bacteriophages (Givan et al., 1982). The studies with lectins and phages specific for TA have shown that much less than the maximum content of TA is sufficient to ensure maximum binding of these probes though the relation depends on the particular probe studied and the conditions employed.

We now report further work on phage binding properties of bacteria containing different amounts of TA which shows a new and unexpected effect of temperature on binding.

$\dagger$ Present address: Quest International, Ashford, Kent TN24 0TK, UK.

Abbreviations: PAE, phage adsorption efficiency; TA, teichoic acid; TU, teichuronic acid. 


\section{METHODS}

Bacterial samples. Bacillus subtilis 168 (trp) was the strain studied by Coley et al. (1975) and was obtained from these authors. Samples of the bacteria, grown under balanced conditions so as to contain different proportions of TA, were obtained as previously described (Lang et al., 1982) and walls were prepared and treated with hot SDS, as before, to remove autolysins and other non-covalently associated proteins. A sample of strain 168 that had been collected between 2 and $3 \mathrm{~h}$ after pulsed release of phosphate limitation was also studied. A sterile solution ( $10 \mathrm{ml})$ containing $100 \mathrm{mg} \mathrm{NaH}{ }_{2} \mathrm{PO}_{4} \cdot 2 \mathrm{H}_{2} \mathrm{O}$ was added to a 3 litre chemostat culture growing at $D=0 \cdot 2 \mathrm{~h}^{-1}$ in phosphatelimiting medium containing $1 \mathrm{~mm}$-phosphate as described by Anderson et al. $(1978 \mathrm{~b})$. The sample collected between 2 and $3 \mathrm{~h}$ contained $42 \mu \mathrm{mol}$ of glucosylglycerol per gram of wall.

Bacteriophage propagation, assay and binding measurement. Phage SP50 was propagated and assayed as previously described (Archibald \& Coapes, 1976). Phage adsorption efficiency (PAE) values, which are proportional to the rate constant of the binding reaction, were determined essentially as before (Archibald $\&$ Coapes, 1976). Lyophilized bacterial and wall samples were dispersed in NBMG medium that contained $2.5 \%$ (w/v) Oxoid nutrient broth and $0.01 \mathrm{M}-\mathrm{MgCl}_{2}$. Bacterial suspensions were taken quickly to $100^{\circ} \mathrm{C}$ for $10 \mathrm{~min}$ to inactivate autolysins, and both bacterial and wall suspensions were dispersed by sonication for $20 \mathrm{~s}$ at low power in an MSE ultrasonic homogenizer, and incubated with phage SP50 $\left(2 \times 10^{5}\right.$ p.f.u. $\left.\mathrm{ml}^{-1}\right)$ for $1 \mathrm{~h}$ at 0 or at $37^{\circ} \mathrm{C}$. Portions $(0.1 \mathrm{ml})$ were withdrawn into NBMG medium $(10 \mathrm{ml})$, mixed, left for $20 \mathrm{~min}$ at room temperature $\left(22^{\circ} \mathrm{C}\right)$ to allow desorption of any reversibly attached phage, and then assayed in duplicate. Where indicated bound phages were removed from incubation mixtures by filtration through Millipore filters $(0.45 \mu \mathrm{M})$ or by centrifugation at $8500 \mathrm{~g}$ for $10 \mathrm{~min}$.

\section{RESULTS}

\section{Effect of incubation temperature on phage-binding properties of bacteria and isolated walls containing varied amounts of TA}

The sample of strain 168 grown in medium that contained $3.0 \mathrm{~mm}$-phosphate had the maximum content of TA, i.e. $1120 \mu \mathrm{mol}$ glucosylglycerol per gram (dry weight) of cell wall (Lang et al., 1982). Phage-binding measurements were done at $37^{\circ} \mathrm{C}$ in suspensions that containing 0 , $2 \cdot 6,5 \cdot 2$ and $10 \cdot 4 \mu \mathrm{g}$ of bacteria $\mathrm{ml}^{-1}$. Bacterial concentration plotted (Fig. 1a) against the logarithm of the concentration of unbound phage gave a straight line $(r=0.997)$ and a PAE of $280 \mathrm{ml} \mathrm{mg}^{-1} \mathrm{~h}^{-1}$. Suspensions containing $0,5 \cdot 2,10 \cdot 4$ and $20.8 \mu \mathrm{g}$ of bacteria $\mathrm{ml}^{-1}$ incubated with phage at $0{ }^{\circ} \mathrm{C}$ gave a straight line $(r=0.999)$ of smaller slope with a PAE of $150 \mathrm{ml} \mathrm{mg}^{-1} \mathrm{~h}^{-1}$. (Fig. 1 a). Since PAE values are directly proportional to the rate constant of the binding reaction, it follows that binding at $0{ }^{\circ} \mathrm{C}$ proceeds at nearly half the rate observed at $37^{\circ} \mathrm{C}$. This difference in rate is similar to that found previously with $B$. subtilis W23 (Archibald $\&$ Coapes, 1976) and other phage-bacterium systems (Tolmach, 1957). However, samples of $B$. subtilis 168 that contained only small proportions of TA showed a striking difference in their ability to bind phage at different temperatures, and bacteria that contained less than half the maximum content of TA bound phage more rapidly at 0 than at $37^{\circ} \mathrm{C}$. Fig. $1(b)$ shows the effect of incubation temperature on binding of phage to cell samples that had been obtained by growth in medium containing $0.85 \mathrm{~mm}$-phosphate. These bacteria contained $484 \mu \mathrm{mol}$ glucosylglycerol per gram of wall, i.e. $43 \%$ of the maximum content of TA. At $0{ }^{\circ} \mathrm{C}$ the rate of phage binding (PAE $=140 \mathrm{ml} \mathrm{mg}^{-1} \mathrm{~h}^{-1}$ ) was closely similar to that of the bacteria grown in $3.0 \mathrm{~mm}^{-}$ phosphate. However, whereas the latter sample bound phage more rapidly at $37^{\circ} \mathrm{C}$, the reverse was true with bacteria grown in $0.85 \mathrm{~mm}$-phosphate, which had a PAE value of only $57 \mathrm{ml}$ $\mathrm{mg}^{-1} \mathrm{~h}^{-1}$ at $37^{\circ} \mathrm{C}$. Semi-logarithmic plots (Fig. $\left.1 b\right)$ gave straight lines at $0{ }^{\circ} \mathrm{C}(r=0.996)$ and at $37^{\circ} \mathrm{C}(r=0.997)$ revealing first-order kinetics at both temperatures.

The effect of incubation temperature on phage binding is related to TA content (Fig. 2). At $37^{\circ} \mathrm{C}$, PAE values fell off fairly regularly with decreasing content of TA but at $0{ }^{\circ} \mathrm{C}$ the PAE values remained nearly constant in bacteria containing down to $43 \%$ of their maximum content of TA. As shown in Fig. 2, bacteria that contained small proportions of TA had greater PAE values at 0 than at $37^{\circ} \mathrm{C}$. Thus, bacteria grown in $0.85 \mathrm{~mm}$ and in $0.65 \mathrm{~mm}$-phosphate bound phage 2.4 and 5.2 times more quickly at the lower temperature (PAE values of 139 and $57 \mathrm{ml} \mathrm{mg}^{-1} \mathrm{~h}^{-1}$, and 52 and $10 \mathrm{ml} \mathrm{mg}^{-1} \mathrm{~h}^{-1}$, respectively, for the two samples at 0 and at $37^{\circ} \mathrm{C}$ ). This phenomenon was also shown with cell walls for which the effect of temperature was even more marked, particularly in the case of walls with very small proportions of TA. Thus walls of 


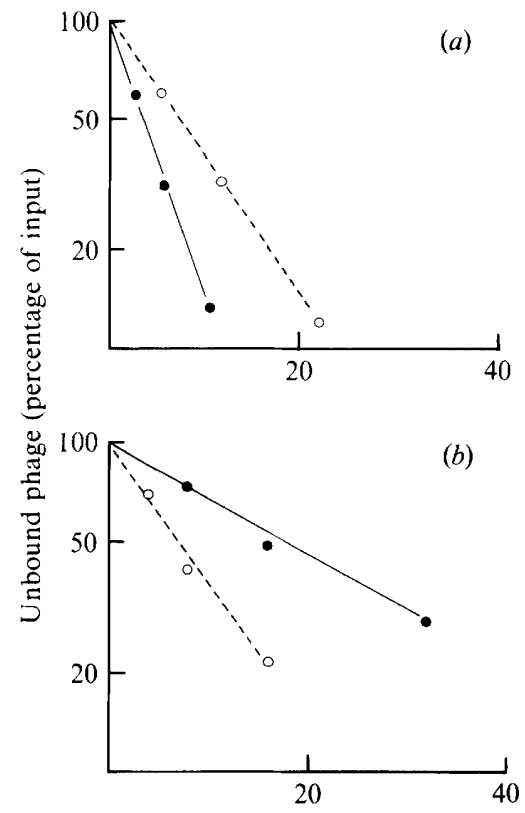

Bacterial concentration $\left(\mu \mathrm{g} \mathrm{ml}^{-1}\right)$

Fig. 1

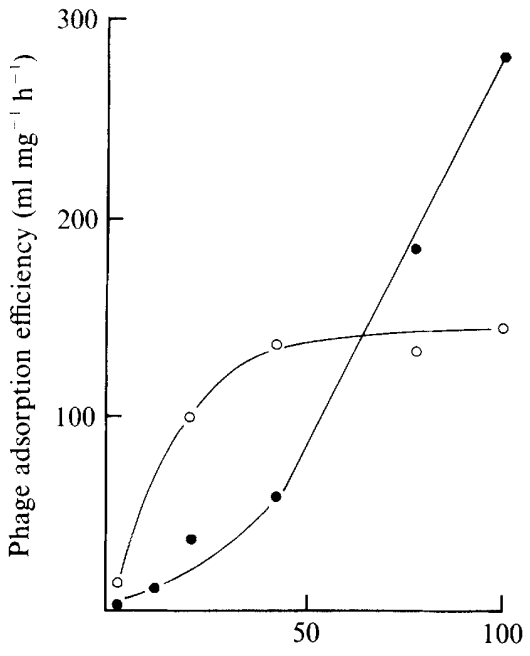

TA content (percentage of maximum)

Fig. 2

Fig. 1. Effect of incubation temperature on the rate of binding of phage SP50 to B. subtilis. Bacteria containing $(a) 1120 \mu \mathrm{mol}$ glucosylglycerol per gram of wall and $(b) 484 \mu \mathrm{mol}$ glucosylglycerol per gram of wall were incubated for $1 \mathrm{~h}$ with phages at $37^{\circ} \mathrm{C}(\mathrm{O})$ and $0{ }^{\circ} \mathrm{C}(\mathrm{O})$. Unbound phage were assayed as described in the text.

Fig. 2. Effect of TA content on the rate of binding of phage SP50 to B. subtilis. Bacteria containing varied amounts of TA were incubated with phage at $37^{\circ} \mathrm{C}(\mathrm{O})$ and $0{ }^{\circ} \mathrm{C}(\mathrm{O})$ and $\mathrm{PAE}$ values were determined.

bacteria grown in $0.85 \mathrm{~mm}$-phosphate bound phage more than five times as quickly at 0 as at $37^{\circ} \mathrm{C}$ (PAE values of $650 \mathrm{ml} \mathrm{mg}^{-1} \mathrm{~h}^{-1}$ at $0^{\circ} \mathrm{C}$ and $120 \mathrm{ml} \mathrm{mg}^{-1} \mathrm{~h}^{-1}$ at $37{ }^{\circ} \mathrm{C}$ ), and walls of bacteria grown in $0.65 \mathrm{mM}$-phosphate bound phage more than 150 times as quickly at 0 as at $37^{\circ} \mathrm{C}$ (PAE values of $150 \mathrm{ml} \mathrm{mg}^{-1} \mathrm{~h}^{-1}$ and $<1 \mathrm{ml} \mathrm{mg}^{-1} \mathrm{~h}^{-1}$ at 0 and $37^{\circ} \mathrm{C}$, respectively).

\section{Effect of incubation temperature on the phage-binding properties of phosphate-pulsed bacteria and walls}

Bacteria that contained small amounts of TA incorporated during pulsed release of phosphate limitation also bound phage more rapidly at 0 than at $37^{\circ} \mathrm{C}$. PAE values obtained for a sample of B. subtilis 168 collected 2 to $3 \mathrm{~h}$ after pulsed release of phosphate limitation were 8 and $35 \mathrm{ml} \mathrm{mg}{ }^{-1} \mathrm{~h}^{-1}$ at 37 and $0^{\circ} \mathrm{C}$, respectively. The effect of temperature was again more marked with walls and a steady decrease in phage binding by the pulsed wall sample was seen (Fig. 3) as the incubation temperature was increased: at $0{ }^{\circ} \mathrm{C} 85 \%$ of the added phage were bound whereas no binding was detected at $37^{\circ} \mathrm{C}$.

\section{Reversibility of phage binding}

A possible explanation of the effect of temperature on the measured phage-binding rates was that the difference was not due to a more rapid binding at the lower temperature but to a more rapid desorption of phage bound at $37^{\circ} \mathrm{C}$ so that the measurements made here at $0{ }^{\circ} \mathrm{C}$ would include reversible as well as any irreversible binding whereas only the latter would be measured at $37^{\circ} \mathrm{C}$. To check this, assays were repeated but with a procedural difference, i.e. bound phage 


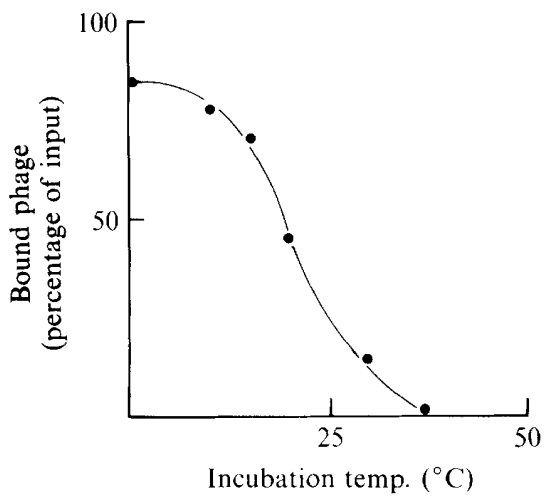

Fig. 3

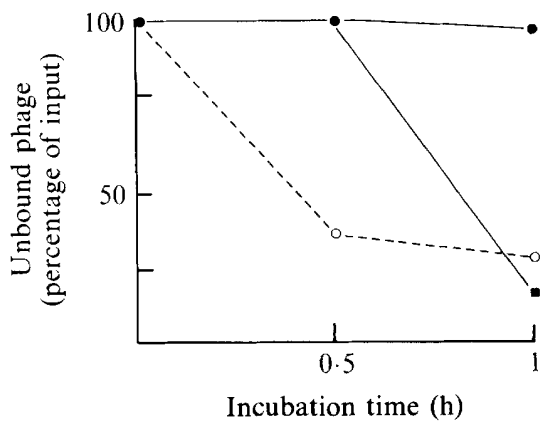

Fig. 4

Fig. 3. Effect of incubation temperature on the binding of phage to walls of phosphate-pulsed $B$. subtilis. Walls $\left(27 \mu \mathrm{g} \mathrm{ml}^{-1}\right)$ were incubated with phage SP50 $\left(2.7 \times 10^{5}\right.$ p.f.u. $\left.\mathrm{ml}^{-1}\right)$ in NBMG medium at different temperatures for $1 \mathrm{~h}$ and unbound phage were assayed.

Fig. 4. Effect of shifts in incubation temperature on the binding of phage to walls of $B$. subtilis. Walls $\left(50 \mu \mathrm{g} \mathrm{ml}^{-1}\right)$, isolated from bacteria grown in $0.65 \mathrm{~mm}$-phosphate and containing $145 \mu \mathrm{mol}$ glycosylglycerol per gram were incubated with phage $\left(2 \times 10^{5}\right.$ p.f.u. $\left.\mathrm{ml}^{-1}\right)$ in NBMG medium and assayed after incubation for 30 and $60 \mathrm{~min}$ at $37^{\circ} \mathrm{C}(\mathrm{O})$, at $37^{\circ} \mathrm{C}$ followed by transfer to $0{ }^{\circ} \mathrm{C}(\mathbf{a})$, and at $0{ }^{\circ} \mathrm{C}$ followed by transfer to $37^{\circ} \mathrm{C}(\mathrm{O})$. Phage suspensions incubated under these conditions in the absence of walls were stable and gave constant titres.

\section{Table 1. Effect of dilution medium on phage-binding assay}

Walls of phosphate-pulsed $B$. subtilis were incubated with phage SP50 under standard conditions for $1 \mathrm{~h}$ at $0^{\circ} \mathrm{C}$. Samples of the incubation mixture were diluted in MBMG medium containing $\mathrm{Mg}^{2+}$ at the concentrations shown, allowed to equilibrate for $30 \mathrm{~min}$ and then assayed in duplicate for free phage particles.

$$
\begin{aligned}
& \mathrm{Mg}^{2+} \text { concn } \\
& \text { in diluent }(\mathrm{M})
\end{aligned}
$$$$
0 \cdot 1
$$$$
0 \cdot 05
$$$$
0.01
$$

$0 \cdot 001$

$\begin{array}{cc}\text { Sample } & \text { Control } \\ 23 & 130 \\ 26 & 130 \\ 31 & 144 \\ 33 & 144\end{array}$

Phage adsorbed $(\%)$

82

80

78

77

were removed by centrifugation before dilution and assay. This will thus account for both reversibly and irreversibly bound phage. However, the results (not presented) were similar to those obtained by dilution showing that the effect of incubation temperature on the measured rate of phage binding is apparently not due to differences in the rate of desorption.

In further experiments we found that the number of unadsorbed phage did not vary greatly when incubation mixtures of phage with pulsed bacteria were diluted in NBMG media in which the $\mathrm{Mg}^{2+}$ concentration varied between $0 \cdot 1$ and $0 \cdot 001 \mathrm{M}$ (Table 1). Also no active phage were recovered when cell-phage complexes formed at either incubation temperature were recovered by filtration and suspended in fresh NBMG medium. The binding measured by both centrifugation and dilution assays is thus effectively irreversible so that the differences, measured as PAE, must reflect those in the rate of attachment. Further support for this was obtained in an experiment (Fig. 4) in which walls from bacteria grown in $0.65 \mathrm{~mm}$-phosphate were incubated with phages at varied temperature. At $37^{\circ} \mathrm{C}$ little or no binding took place, though following incubation at that temperature a shift to $0{ }^{\circ} \mathrm{C}$ resulted in rapid binding. An incubation set up at $0{ }^{\circ} \mathrm{C}$ showed rapid binding: following a shift to $37^{\circ} \mathrm{C}$ no phage were 
desorbed, though little further binding took place. The effect of incubation temperature is therefore an effect on binding and not desorption. Since the collision frequency will be at least as high at 37 as at $0{ }^{\circ} \mathrm{C}$ it follows that samples that have PAE values greater at 0 than at $37^{\circ} \mathrm{C}$ must bind phage more effectively at the lower temperature.

\section{Kinetics of binding}

B. subtilis 168 grown in $3.0 \mathrm{~mm}$-phosphate had a PAE value of $280 \mathrm{ml} \mathrm{mg}^{-1} \mathrm{~h}^{-1}$ when incubated in NBMG medium with SP50 at $37^{\circ} \mathrm{C}$ (see above). The rate constant of the pseudofirst-order binding reaction is therefore $194 \mathrm{ml} \mathrm{mg}^{-1} \mathrm{~h}^{-1}$ (i.e. PAE $\times \ln 2$; Archibald \& Coapes, 1976). This rate constant can be expressed in terms of bacterial number rather than weight. Electron microscopy indicates that $B$. subtilis growing in the chemostat at $D=0.2 \mathrm{~h}^{-1}$ has an average cell size of about $0.5 \times 2 \mu \mathrm{m}$ (Anderson et al., 1978b) so that the average cell volume is about $0.39 \mu \mathrm{m}^{3}$. Assuming that the density and ratio of dry weight to wet weight for the bacteria are similar to those reported for Escherichia coli, i.e. $1 \cdot 12 \mathrm{~g} \mathrm{~cm}^{-3}$ and $27 \%$ respectively (Koch \& Blumberg, 1976), then the average dry weight of one bacillus is $0.12 \mathrm{pg}$. From this, the adsorption rate constant for binding of SP50 to whole bacteria can be expressed as $3.9 \times 10^{-10}$ $\mathrm{cm}^{3} \mathrm{~min}^{-1}$. This may be compared with the theoretical maximum adsorption rate constant calculated assuming $100 \%$ collision efficiency from the relation $k_{\max }=4 \pi D a$, where $a$ is the radius of a sphere of the same surface area as the bacterium and $D$ is the diffusion constant of the phage (Schlessinger, 1933). From the dimensions given above the radius of a sphere with the same surface area as an average cell of $B$. subtilis is $0.45 \mu \mathrm{m}$. The sedimentation constant, morphology and size of phage SP50 are similar to those of phage T4 (Foldes \& Trautner, 1964) and so SP50 should have a diffusion constant similar to that of T4, i.e. $1.77 \times 10^{-6} \mathrm{~cm}^{2} \mathrm{~min}^{-1}$ (Dubin et al., 1970). These values provide for SP50 a $k_{\max }$ of about $10^{-9} \mathrm{~cm}^{3} \mathrm{~min}^{-1}$, which is not significantly different from the experimental value obtained here, i.e. $0.39 \times 10^{-9} \mathrm{~cm}^{3} \mathrm{~min}^{-1}$. Similar differences between experimental and theoretical values have been observed for other phage-bacterium systems (Tolmach, 1957; Schwartz, 1976).

\section{DISCUSSION}

The agreement found here between experimental and theoretical values for the rate of binding of phage SP50 to B. subtilis 168 has been observed with other phage-bacterium systems (see Schwartz, 1976) and shows that most collisions lead to adsorption so that the binding reaction has a high overall efficiency, and remains high even at low temperatures. The rather small reduction in maximum rate of binding at $0^{\circ} \mathrm{C}$ as compared to that at $37^{\circ} \mathrm{C}$, as observed here and in earlier work (Archibald \& Coapes, 1976) may be ascribed to a reduction in collision frequency resulting from the increased viscosity of the suspending medium at the lower temperature (Tolmach, 1957).

As measured here binding at $0{ }^{\circ} \mathrm{C}$ was irreversible. Schwartz (1976) showed that the rate of dissociation of phage $\lambda$ from its receptor was dependent on the concentration of $\mathrm{Mg}^{2+}$; the binding appeared to be irreversible under some conditions but not others. We did not find conditions under which binding of phage SP50 at $0{ }^{\circ} \mathrm{C}$ could be shown to be reversible though the high rate of the reaction suggests that it does not involve covalent change. Thus, this may be another example of the very slowly reversible binding described by Schwartz (1976). The observation that phages adsorbed to walls during incubation at $0{ }^{\circ} \mathrm{C}$ appear to have retained their DNA within the phage heads (Archibald, 1976) is consistent with this interpretation.

A high collision efficiency appears to be inconsistent with the specificity of the interaction between phages and host bacteria. To explain this it has been suggested that only some of the charged groups of the receptors are involved in the initial interaction which serves to hold the phage in position until more groups can interact (Puck et al., 1957). Another suggestion is that the flexible phage tail or tail fibres can 'sweep' a relatively large area of the bacterial surface in the time the phage is in contact with the surface (Schwartz, 1976). Berg \& Purcell (1977) have shown that following the first collision there is a high probability that the phage will collide repeatedly with the bacterial surface before moving away if none of these collisions leads to 
adsorption. If the receptor density is high enough the phage will always 'find' a receptor. If the affinity is also high every collision will be effective, and the greater the affinity the lower the density needed to ensure maximum adsorption efficiency.

The relationship found here between receptor density (i.e. TA content) in B. subtilis and the rate of phage SP50 binding at $0{ }^{\circ} \mathrm{C}$ is similar to that reported for binding of phage $\lambda$ to $E$. coli containing varied amounts of the receptor, the LamB protein (Schwartz, 1976). Binding rate increases with receptor density up to a limit but further increases in receptor density have no perceptible effect on binding rate which is close to the theoretical maximum, even with bacteria that contain considerably less than the maximum receptor density.

The finding that bacteria that contain only small amounts of TA bind phage more slowly at 37 than at $0{ }^{\circ} \mathrm{C}$ shows that the higher temperature reduces either the receptor density or the affinity between phage SP50 and its receptor so that at $37^{\circ} \mathrm{C}$ the higher collision frequency will be outweighed by reduced collision efficiency. The binding rate at both temperatures increases with increasing receptor (TA) density but reaches its maximum at $0{ }^{\circ} \mathrm{C}$ with bacteria that contain less TA than needed to give the maximum binding at $37^{\circ} \mathrm{C}$ (Fig. 2). Indeed, at $0{ }^{\circ} \mathrm{C}$ the maximum binding is shown by bacteria that contain only $43 \%$ of the maximum content of TA but at $37{ }^{\circ} \mathrm{C}$ the rate of binding increases with further increases in TA. Eventually, the rate at $37^{\circ} \mathrm{C}$ exceeds that at $0{ }^{\circ} \mathrm{C}$ and the maximum rate is reached with bacteria containing the maximum amount of $\mathrm{TA}$.

The structural basis of the effect of incubation temperature on the receptor density or phage-receptor affinity is not known. It could involve either a temperature-dependent change in conformation of phage adsorption proteins, altering their affinity for the receptor, or a change in the bacterial surface, affecting the organization of the TA and influencing the effective concentration of the receptor or its affinity for phage. Alteration of phage adsorption proteins does not explain why binding to isolated walls is more markedly affected by temperature than is binding to whole bacteria. This could, however, be explained on the basis of a lowered structural integrity of wall material in isolated walls as compared to whole bacteria. Removal of noncovalently associated components by extraction with the hot SDS solution used in the wall isolation procedure could affect the packing of residual wall components and make them more susceptible to temperature-induced changes. Since the activity of the receptor material depends on its organization in particulate wall material (see Archibald, 1980) this could readily explain the greater effect of temperature on phage binding to isolated walls.

While no such observations have been made on TA, other acidic polysaccharides are known to undergo conformational changes with temperature (Rees, 1972). Factors other than temperature are known to affect the conformation of TA (Doyle et al., 1974) and the organization of wall polymers (Archibald, 1988), and it is possible that both temperature and ionic environment interact to determine surface structure.

We thank the Medical Research Council for financial support.

\section{REFERENCES}

Anderson, A. J., Green, R. S. \& Archibald, A. R. $(1978 a)$. Wall composition and phage binding properties of Bacillus subtilis W23 grown in chemostat culture in media containing various concentrations of phosphate. FEMS Microbiology Letters 4, 129-132.

Anderson, A. J., Green, R. S., Sturman, A. J. \& ARCHIBALD, A. R. (1978b). Cell wall assembly in Bacillus subtilis: location of wall material incorporated during pulsed release of phosphate limitation, its accessibility to bacteriophages and concanavalin A, and its susceptibility to turnover. Journal of Bacteriology 136, 886-899.

ARCHIBALD, A. R. (1976). Cell wall assembly in Bacillus subtilis: development of bacteriophage binding properties as a result of the pulsed incorporation of teichoic acid. Journal of Bacteriology 127, 956960.

ARChibald, A. R. (1980). Phage receptors in Gram positive bacteria. In Virus Receptors, part 1, Receptors and Recognition, series B, pp. 5-26. Edited by P. Cuatrecasas \& M. F. Greaves. London: Chapman and Hall.

ARCHIBALD, A. R. (1988). Bacterial cell wall structure and the ionic environment. In Homeostatic Mechanisms and the Ionic Environment, pp. 37-51. Edited by R. Whittenbury, G. W. Gould, J. G. Baker \& R. Board. Bath: Bath University Press.

ARChibald, A. R. \& CoAPES, H. E. (1976). Bacteriophage SP50 as a marker for cell wall growth in Bacillus subtilis. Journal of Bacteriology 125, 11951206. 
Berg, H. C. \& Purcell, E. M. (1977). Physics of chemoreception. Biophysical Journal 20, 193-219.

Coley, J., Duckworth, M. \& Baddiley, J. (1975). Extraction and purification of lipoteichoic acids from Gram-positive bacteria. Carbohydrate Research 40, 41-52.

Doyle, R. J., McDannel, M. J., Streips, U. N., Birdsell, D. C. \& Young, F. E. (1974). Polyelectrolyte nature of bacterial teichoic acids. Journal of Bacteriology 118, 606-615.

Dubin, S. B., BenedeK, G. B., Bancroft, F. C. \& Freifelder, D. (1970). Molecular weights of coliphages and coliphage DNA. 2. Measurement of diffusion coefficients using optical mixing spectroscopy and measurement of sedimentation coefficients. Journal of Molecular Biology 54, 547-556.

Elwood, D. C. \& Tempest, D. W. (1969). Control of teichoic acid and teichuronic acid biosynthesis in chemostat cultures of Bacillus subtilis var niger. Biochemical Journal 111, 1-5.

Foldes, J. \& Trautner, T. A. (1964). Infectious DNA from a newly isolated Bacillus subtilis phage. Zeitschrift für Vererbungslehre 95, 57-65.

Givan, A. L., Glassey, K., Green, R. S., Lang, W. K., Anderson, A. J. \& ArChibald, A. R. (1982). Relation between wall teichoic acid content of Bacillus subtilis and efficiency of adsorption of bacteriophages SP50 and $\phi 25$. Archives of Microbiology 133, 318--322.

JAMES, A. \& BREWER, J. E. (1978). Non-protein components of the cell surface of Staphylococcus aureus. Biochemical Journal 107, 817-821.

KoCH, A. L. \& BlumberG, G. (1976). Distribution of bacteria in the velocity gradient centrifuge. Biophysical Journal 16, 389-405.
LANG, W. K. \& ARchibald, A. R. (1983). Relation between cell wall teichoic acid content and concanavalin A binding in Bacillus subtilis 168. FEMS Microbiology Letters 20, 163-166.

LanG, W. K., Glassey, K. \& ARChibald, A. R. (1982). Influence of phosphate supply on the teichoic and teichuronic acid content of Bacillus subtilis walls. Journal of Bacteriology 151, 367-375.

OU, L. T. \& MARQUIS, R. E. (1970). Electromechanical interactions in cell walls of Gram positive cocci. Journal of Bacteriology 101, 92-101.

Puck, T. T., Garen, A. \& Cline, J. (1951). The mechanism of virus attachment to host cells. 1 . The role of ions in the primary reaction. Journal of Experimental Medicine 93, 65-88.

REES, D. A. (1972). Shapely polysaccharides: the eighth Colworth Medal lecture. Biochemical Journal 126, 257-263.

Schlessinger, M. (1933). Uber die Bindung des Bakteriophagen an homologe Bakterien. 2. Mitteilung. Quantitative Untersüchungen über die Bindungsgeschwindigkeit und die Sattigung Berechnung der Teilchengrosse des Bakteriophagen aus deren Ergebnissen. Zeitschrift für Hygiene und Infektionskrankheiten 114, 149-160. (Reprinted in translation, 1960. In Papers on Bacterial Viruses, pp. 26-36. Edited by G. S. Stent. Boston: Little, Brown \& Co.)

Schwartz, M. (1976). The adsorption of coliphage lambda to its host: effect of variations in the surface density of receptor and in phage receptor affinity. Journal of Molecular Biology 103, 521-536.

TolmaCH, L. J. (1957). Attachment and penetration of cells by viruses. Advances in Virus Research 4, 63110. 